\title{
Research Article: Difficulties faced by the members about working of the self-helf groups
}

\author{
Rupatai D. Kadte, S.U. Mokhale, D.G. Padekar and V.K. Dere
}

Article Chronicle : Received :

22.05.2018;

Revised :

15.06.2018;

Accepted :

29.06.2018

KeY Words:

Difficulties, SHGs, SHG members, Meeting, Membership, Loan, Finance, Self help
SUMMARY : The present study on difficulties faced by the members about working of the self-help groups was conducted in Amravati district of Maharashtra state. The sample was drawn from the three talukas viz., Chandur bazaar, Morshi, and Chandur Railway with the specific objective. Thus, 80 SHG members were selected which constituted the sample respondents for the present study. Data were collected by personally interviewing the respondents with the help of pre-tested structured interview schedule in face to face situation. Thereafter, collected data were tabulated. The difficulties faced by the members while working in SHG were identified by eliciting the response of SHG members through an open-end question. The difficulties were recorded and presented in term of frequencies and percentages. Findings indicate that in the self help groups difficulties which influence the knowledge of members about working of SHGs were lack of time for meeting and training $(62.50 \%)$, improper utilization of finance (65.00\%), poor economic conditions $(76.25 \%)$, improper guidance by the trainers and managing staff $(50.00 \%)$, ignorance of members $(65.00 \%)$, non co-operative attitude among the members $(72.50 \%)$, inadequate financial assistance $(56.25 \%)$, lack of unity $(75.00 \%)$, inadequate training facilities $(68.75 \%)$ and conflict among the members $(43.75 \%)$.

How to cite this article : Kadte, Rupatai D., Mokhale, S.U., Padekar, D.G. and Dere, V.K. (2018). Difficulties faced by the members about working of the self-helf groups. Agric. Update, 13(3): 289-292; DOI : 10.15740/ HAS/AU/13.3/289-292. Copyright@ 2018: Hind Agri-Horticultural Society.
Author for correspondence :

\section{S.U. Mokhale}

Department of

Extension Education,

Shri Shivaji Agricultural

College, Amravati (M.S.)

India

Email:shekharmokhale17

@ gmail.com

See end of the article for

authors' affiliations 